\title{
Distribution of perch (Perca fluviatilis L.) during their first year of life in Lake Constance
}

\author{
Ning Wang \& Reiner Eckmann* \\ Limnological Institute, University of Constance, D-78464 Konstanz, Germany; * Present address: Institute \\ of Freshwater and Fisheries Ecology, Müggelseedamm 310, D-12587 Berlin, Germany
}

Received 18 November 1992; in revised form 4 May 1993; accepted 29 June 1993

Key words: Perca fluviatilis, larvae, juveniles, distribution, diel activity patterns, cannibalism

\begin{abstract}
The distribution and behaviour of larval and juvenile perch (Perca fluviatilis L.) were studied for two years in large, deep Lake Constance. After hatching larvae were transported by water currents to the open water. The majority of larvae remained in the pelagic zone for about one month. In both years, their return to the littoral zone coincided with the decline of pelagic zooplankton abundance. After returning to the littoral zone, juveniles stayed among submerged macrophytes within $5 \mathrm{~m}$ depth and lived apart from larger perch which lived at depths of 6-20 m. By late summer, juveniles changed their distribution pattern: during the day they stayed intensively close to piers and ports, but increased their swimming activity at dusk, cruising among shallow and deep waters and feeding on zooplankton, and rested on the bottom at night. This behaviour appears to be related to the decrease of inshore food resources and to the presence of predators in deeper water. $0^{+}$perch left the littoral zone and moved into deep waters when autumnal mixing began in late October. They overwintered near the bottom at depths of more than $30 \mathrm{~m}$. During most of the year, juvenile and adult perch were separated from each other. But as soon as they occupied the same habitat, the occurrence of cannibalism increased.
\end{abstract}

\section{Introduction}

In a variety of lakes the distribution patterns of young Eurasian perch Perca fluviatilis L., and of the closely related yellow perch, Perca flavescens (Mitchill), are very similar: after hatching the larvae move to the pelagic zone and remain there for 1-2 months and then return to the littoral zone. However, different hypotheses exist as to the reasons for these movements (cf. Post \& McQueen, 1988). Post \& McQueen (1988) suggested that within the generalized pattern of early life history migrations in Perca spp., the timing of offshore and inshore migration may be rather flexible both between and within populations. Based upon this concept, the first aim of our study was to investigate the large scale distribution patterns of young perch in a large, deep lake in relation to prey abundance and predation risk. Most studies on the distribution of young perch were only confined to the growing season, so very little information on $0^{+}$perch behaviour after summer is available. Therefore, our second aim was to study the distribution and behaviour of $0^{+}$perch during autumn and winter. 


\section{Materials and methods}

Lake Constance is a large $\left(539 \mathrm{~km}^{2}\right)$ and deep (maximum depth $252 \mathrm{~m}$ ) lake of meso-eutrophic state and warm-monomictic character. Thermal stratification begins in mid-March and autumnal mixing begins in October. The perch is the second most important commercial species (to whitefish, Coregonus spp.), and adult perch are the main predators of young perch. The present study was carried out from April 1990 to February 1992 in Überlinger See, which is a fjord-like bight of Lake Constance and has an area of $65 \mathrm{~km}^{2}$ and a maximum depth of $147 \mathrm{~m}$. Spawning time was determined from samples of adult perch, which were taken weekly with bottomset gill nets $(32,38$ and $42 \mathrm{~mm}$ bar mesh) at water depths of 5-15 m during April and May. From the end of May to midAugust the distribution of larval and juvenile perch was assessed with conical plankton nets of $1.1 \mathrm{~m}$ and $1.4 \mathrm{~m}$ diameter. Mesh sizes were progressively increased $(200,500,900$ and $1200 \mu \mathrm{m})$ as fish grew larger. The nets were pulled from a boat ( $9 \mathrm{~m}$ long, $55 \mathrm{HP}$ engine). Towing depth was adjusted by $5-20 \mathrm{~kg}$ weights fixed at the net ring, and towing depth was calculated from the angle of inclination and the length $(46 \mathrm{~m})$ of the towing rope. Towing speed was maintained at $0.5 \mathrm{~m} \mathrm{~s}^{-1}$ for early larvae and at $1.5 \mathrm{~m} \mathrm{~s}^{-1}$ for juveniles. Tows lasted for about 5 minutes. A digital flowmeter was fixed in the center of the net opening, and the number of fish per unit volume could be estimated.

Three standard towing sites were established from the sheltered southwestern shore to the middle of the lake: (1) nearshore, over the $2 \mathrm{~m}$ contour; (2) offshore, over the $40 \mathrm{~m}$ contour at about $500 \mathrm{~m}$ distance from the shore; and (3) pelagic, over the $100 \mathrm{~m}$ contour at about $1000 \mathrm{~m}$ from the shore. During the first two weeks after hatching in both study years, larvae were sampled at various depths between 0 and $8 \mathrm{~m}$ (details in 'Results') during the day between 11.00 and 16.00 . Afterwards, they were sampled at depths of 0-2 m at night between 23.00 and 2.00. To evaluate whether there is a diel horizontal migration (Post \& McQueen, 1988), an extra towing site was established in 1990 over the $15 \mathrm{~m}$ contour which was about $50 \mathrm{~m}$ offshore from the nearshore towing site. Samples of zooplankton were taken as vertical hauls from the upper $0-2$ or $0-5 \mathrm{~m}$ at the three standard towing sites. A conical net of $30 \mathrm{~cm}$ diameter with $55 \mu \mathrm{m}$ mesh size was used in May and June, and afterwards an Apstein net with $17 \mathrm{~cm}$ opening and $335 \mu \mathrm{m}$ mesh size. Samples were enumerated by aliquots.

The distribution and diel activity patterns of $0^{+}$perch in the littoral zone were directly observed weekly or biweekly by boating along various types of the shore as well as from piers and ports. Fish nighttime distribution was observed underwater by scuba divers: two divers swam side by side along six $20 \mathrm{~m}$ long lines exposed at the $2,5,10,15,20$ and $25 \mathrm{~m}$ depth contours, and they counted the number of $0^{+}$perch which appeared in the field of vision ( $4 \mathrm{~m}$ wide) of two 100 watt electric torches. Additionally, bottomset gill nets of 10 and $14 \mathrm{~mm}$ bar mesh were used.

To monitor the distribution of large perch, gill netting was continued all year round, and the operations of two professional fishermen were recorded. From their catches, stomach samples were inspected for evidence of cannibalism.

\section{Results}

\section{Distribution of larvae and juveniles}

Perch spawned from the end of April to the end of May in both years. Mass spawning occurred between 21 and 24 May (36-84\% of the caught females had spawned) in 1990, and between 16 and 22 May $(28-73 \%)$ in 1991. The efforts to collect the newly hatched larvae were unsuccessful in 1990 . Only a few larvae were found in the pelagic zone on 31 May and 5 June. During that period, there were strong southwesterly winds (unpublished data from Limnol. Inst. Constance). On 12 June, some postlarvae were caught at about $6 \mathrm{~m}$ depth in the pelagic zone but no larvae were found in the littoral zone (Fig. 1a). After midJune it turned out difficult to catch larvae during the day at whatever depth, while at night high 


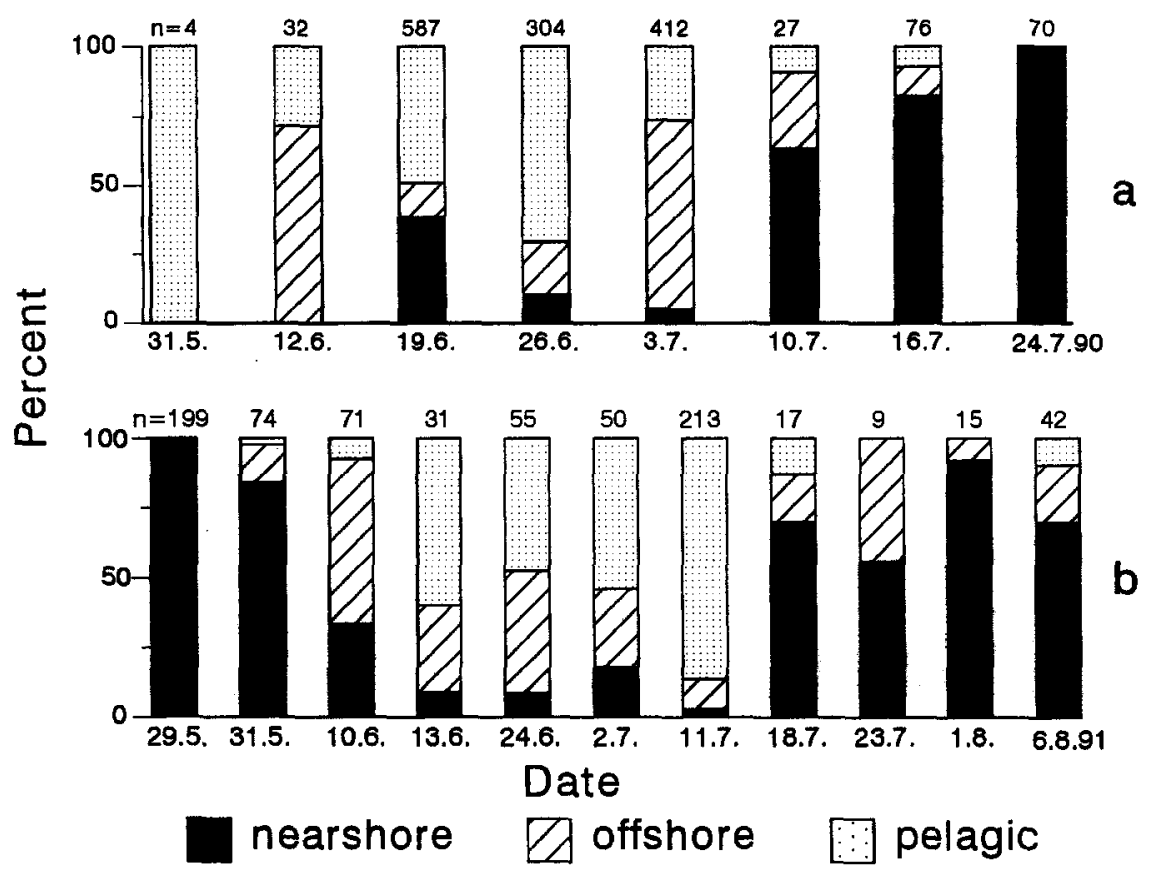

Fig. 1. Horizontal distribution of larval and juvenile perch as a percentage of the cumulative number of fish per unit volume at three sampling sites in lake Constance-Überlinger See in 1990 (upper panel) and 1991 (lower panel).

numbers of larvae could be sampled at the surface (only a few larvae were found below $2 \mathrm{~m}$ deep). Therefore, from this time on sampling took place at night. From mid-June to early July, a part of the population was found in inshore waters, but the majority stayed in the pelagic zone. In the second half of June, the mean lengths of larvae were significantly higher at the nearshore site than at the pelagic site (Duncan's multiple range test, $p<0.05$; Table 1). From 10 July on, an increasingly higher proportion of juveniles was found in the littoral zone, and by the end of July juveniles could only be caught in the littoral zone. There was no evidence for a nighttime offshore migration to the $15 \mathrm{~m}$ contour, once the fish had reached shallow littoral waters (Table 2). This is where large perch were mainly distributed according to gill net samples. From 43 large perch caught at depths of $10-15 \mathrm{~m}$ on $30 \mathrm{July}$, no cannibalism was observed.

A similar distribution pattern was found in 1991. On 29 and 31 May, large numbers of newly hatched perch were found at the surface in the littoral zone (Fig. 1b). Ten days later, most larvae were found outside the littoral zone. During that period, the wind directions were variable. The majority of larvae remained in the pelagic zone for about one month, at which time the mean lengths of larvae at the nearshore site were not higher than at the pelagic site as in the previous year $(p>0.05$; Table 1). Most juveniles returned to the littoral zone during the second half of July, i.e., later than in the previous year. A small fraction of the population stayed in the pelagic zone until early August.

Between late May and early June 1991, approximately 100 large perch were caught near to the nearshore site where large numbers of early larvae were found, and inspected for cannibalism, but only zooplankton was found in their stomachs. Around mid-July 1991, when early juveniles began to migrate inshore, cannibalism was occasionally observed by the fishermen. From our catch on $16 \mathrm{June}, 10 \%$ of perch $(19-25 \mathrm{~cm} \mathrm{TL}$, $n=10$ ) had fed on juvenile perch.

After the return to the littoral zone, juvenile perch shoaled and swam within or close to submerged macrophyte stands at water depths of less 
Table 1. Mean total lengths $(\mathrm{mm}) \pm 1 \mathrm{SD}$ and sample size (in brackets) of larval and juvenile perch collected at three sampling sites in Lake Constance-Überlinger See. For the same sampling date, mean lengths sharing the same letter are not significantly different $(p=0.05)$.

\begin{tabular}{|c|c|c|c|}
\hline Date & Nearshore & Offshore & Pelagic \\
\hline 31.5 .1990 & - & - & $7.2 \pm 1.4(4)$ \\
\hline 12.6 & - & $11.5 \pm 2.1(20)^{\mathrm{a}}$ & $10.4 \pm 2.0(6)^{\mathrm{a}}$ \\
\hline 19.6 & $18.9 \pm 1.7(25)^{\mathrm{a}}$ & $15.5 \pm 2.7(25)^{b}$ & $14.8 \pm 2.7(25)^{b}$ \\
\hline 26.6 & $22.4 \pm 2.2(24)^{\mathrm{a}}$ & $20.9 \pm 3.0(16)^{\mathrm{a}}$ & $16.7 \pm 2.6(25)^{b}$ \\
\hline 3.7 & $25.8 \pm 3.0(19)^{\mathrm{a}}$ & $25.3 \pm 2.8(25)^{\mathrm{a}}$ & $23.8 \pm 4.1(25)^{\mathrm{a}}$ \\
\hline 10.7 & $26.6 \pm 3.7(15)^{\mathrm{ab}}$ & $27.0 \pm 3.0(10)^{\mathrm{a}}$ & $24.3 \pm 2.3(13)^{\mathrm{b}}$ \\
\hline 16.7 & $29.9 \pm 4.0(25)^{\mathrm{a}}$ & $27.8 \pm 2.2(5)^{\mathrm{a}}$ & $25.3 \pm 4.8(4)^{\mathrm{a}}$ \\
\hline 24.7 & $38.3 \pm 3.9(25)$ & - & - \\
\hline 29.5 .1991 & $6.7 \pm 0.9(20)$ & - & - \\
\hline 31.5 & $5.5 \pm 0.4(20)^{\mathrm{a}}$ & $5.3 \pm 0.6(14)^{\mathrm{a}}$ & - \\
\hline 10.6 & $7.9 \pm 1.2(19)^{\mathrm{a}}$ & $8.7 \pm 0.8(20)^{a}$ & $8.1 \pm 0.7(7)^{\mathrm{a}}$ \\
\hline 13.6 & $7.9 \pm 1.7$ & $9.5 \pm 0.9(10)^{\mathrm{a}}$ & $10.3 \pm 1.5(18)^{\mathrm{a}}$ \\
\hline 24.6 & $11.4 \pm 1.0(4)^{b}$ & $13.3 \pm 1.4(20)^{\mathrm{a}}$ & $13.6 \pm 1.3(17)^{a}$ \\
\hline 2.7 & $17.7 \pm 2.8(11)^{\mathrm{a}}$ & $18.2 \pm 2.0(17)^{\mathrm{a}}$ & $17.9 \pm 2.0(20)^{\mathrm{a}}$ \\
\hline 11.7 & $26.4 \pm 5.5(7)^{\mathrm{a}}$ & $27.8 \pm 3.4(20)^{\mathrm{a}}$ & $26.3 \pm 3.3(20)^{\mathrm{a}}$ \\
\hline 18.7 & $30.8 \pm 3.9(13)$ & $27.0 \pm 0.5$ & $29.0 \pm 2.3$ \\
\hline 23.7 & $32.1 \pm 1.8(5)^{b}$ & $36.9 \pm 1.7(4)^{\mathrm{a}}$ & - \\
\hline 1.8 & $46.8 \pm 4.7(9)$ & $40.2 \quad$ (1) & - \\
\hline 6.8 & $52.1 \pm 3.6(27)^{\mathrm{a}}$ & $48.6 \pm 5.1(11)^{a}$ & $47.7 \pm 3.7(4)^{\mathrm{a}}$ \\
\hline
\end{tabular}

than $5 \mathrm{~m}$. They could hardly be found in regions where no submerged macrophyts existed. In large perch $(15-26 \mathrm{~cm}$ TL) caught in our and the fishermen's nets in August and September, no cannibalism was onserved.

\section{Zooplankton abundance in the littoral and pelagic zone}

Before mid-June 1990, when rotifers and copepod nauplii were the main food of perch larvae (Wang, in press), rotifer abundances were similar at all three sampling sites (Fig. 2, upper panel), but higher nauplius densities occurred in the pelagic zone except for $18 \mathrm{June}$ (Fig. 2, middle panel). After mid-June, when young perch fed mainly on copepods and cladocerans, the crustacean abundance in the pelagic zone was generally higher than in the littoral zone, but decreased considerably during the first half of July (Fig. 2, lower panel). The seasonal course of crustacean biomass over the entire pelagic water column of $140 \mathrm{~m}$ (unpublished data from Geller, Limnol.
Institute, Constance) also showed a large decrease of zooplankton abundance during the first half of July (Fig. 3, upper panel, see Daphnia galeata). D. galeata is the most important prey for young perch, while many other species are mostly distributed deeper than $10 \mathrm{~m}$ during the day (Geller,1986). In 1991, however, D. galeata was abundant until mid-July (Fig. 3, lower panel).

Table 2. Nighttime number (ind $1000 \mathrm{~m}^{-3}$ ) of larval and juvenile perch at tow sampling sites and total number of fish sampled per date in Lake Constance-Überlinger See, 1990.

\begin{tabular}{rccc}
\hline Date & $\begin{array}{l}\text { Over } 2 \mathrm{~m} \\
\text { contour }\end{array}$ & $\begin{array}{l}\text { Over } 15 \mathrm{~m} \\
\text { contour }\end{array}$ & $\begin{array}{l}\text { Total } \\
\text { number }\end{array}$ \\
\hline 19.6 & 365 & 118 & 298 \\
26.6 & 55 & 30 & 46 \\
3.7 & 23 & 43 & 64 \\
10.7 & 21 & 9 & 25 \\
16.7 & 47 & 27 & 87 \\
24.7 & 111 & 0 & 70 \\
8.8 & 35 & 0 & 23 \\
20.8 & 12 & 0 & 18 \\
\hline
\end{tabular}




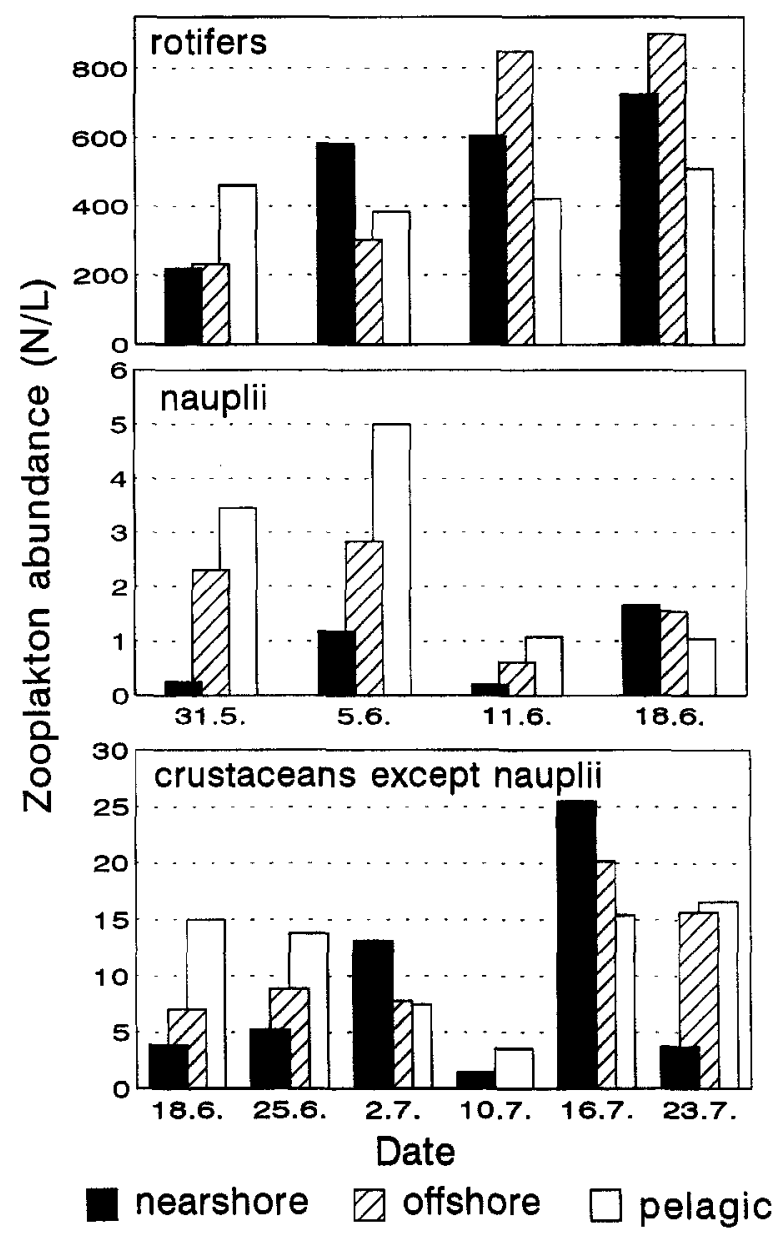

Fig. 2. Zooplankton abundance at three sites in Lake Constance-Überlinger See in 1990.

After the return to the littoral zone, juveniles still consumed mainly zooplankton (Wang, in press). Zooplankton densities in the littoral zone fluctuated widely between 2 and 105 ind $1^{-1}$ from June to August, but afterwards density did not exceed 3 ind $1^{-1}$ throughout autumn (Fig. 3).

\section{Diel activity patterns of $0^{+}$perch}

By the end of August, the behaviour of $0^{+}$perch changed markedly. While boating along the shore, shoals of young perch could not be found within or near to declining submerged macrophyte stands but at piers and ports. In the daytime, they were rather inactive and formed large shoals. At dusk, schooling behaviour was more intense and swimming activity increased. They cruised among both shallow and deep waters, and fed intensively on zooplankton. After dusk shoals broke up, and the fish rested on or slightly above the bottom at depths of 2-5 m (cf. 10 September in Table 3). At dawn they swam up and re-established their daytime distribution. From mid-September onwards shoals extended towards deeper waters. During cloudy or foggy days, $0^{+}$perch were distributed at the lakeward side of port constructions. At night they were most abundant at $10 \mathrm{~m}$ on $11 \mathrm{Oc}-$ tober (Table 3). During sunny days, however, many $0^{+}$perch concentrated in shallow waters of less than $2 \mathrm{~m}$ depth inside of ports. The diel activity pattern which was detected by direct observation was also verified by netting: the highest catch-per-effort was obtained during twilight (Table 4). During this period, cannibalism was frequently observed. From four catches of perch $(18-26 \mathrm{~cm} \mathrm{TL})$ in October, the frequency of occurrence of cannibalism was $6 \%(n=80), 9 \%$ $(n=68), 13 \%(n=82)$ and $10 \%(n=30)$.

\section{Overwintering of $0^{+}$perch}

During violent storms in late October of both years, water temperature decreased sharply from 14.0 to $10.3{ }^{\circ} \mathrm{C}$ (at $1 \mathrm{~m}$ depth) in 1990 and from 15.3 to $11.4{ }^{\circ} \mathrm{C}$ in 1991 within a few days. At that time, $0^{+}$perch disappeared from the littoral zone. From November 1990 to early March 1991, only a few $0^{+}$perch were occasionally caught in bottom-set gill nets at depths of 30-60 m. While at the same time and site large mesh sizes yielded high numbers of adult perch, among which none had eaten younger conspecifics.

In autumn 1991 the retreat of $0^{+}$perch to deeper waters was monitored more regularly by divers (Table 3). While in September and early October $0^{+}$perch were concentrated in shallow waters of less than $10 \mathrm{~m}$ depth during the night, they disappeared almostly completely from this region after the sudden drop in water temperature by late October. During late October and early November, $0^{+}$perch were found at more than $15 \mathrm{~m}$ depth, and the highest abundance was registered at $25 \mathrm{~m}$ depth. At that time, $0^{+}$perch and 

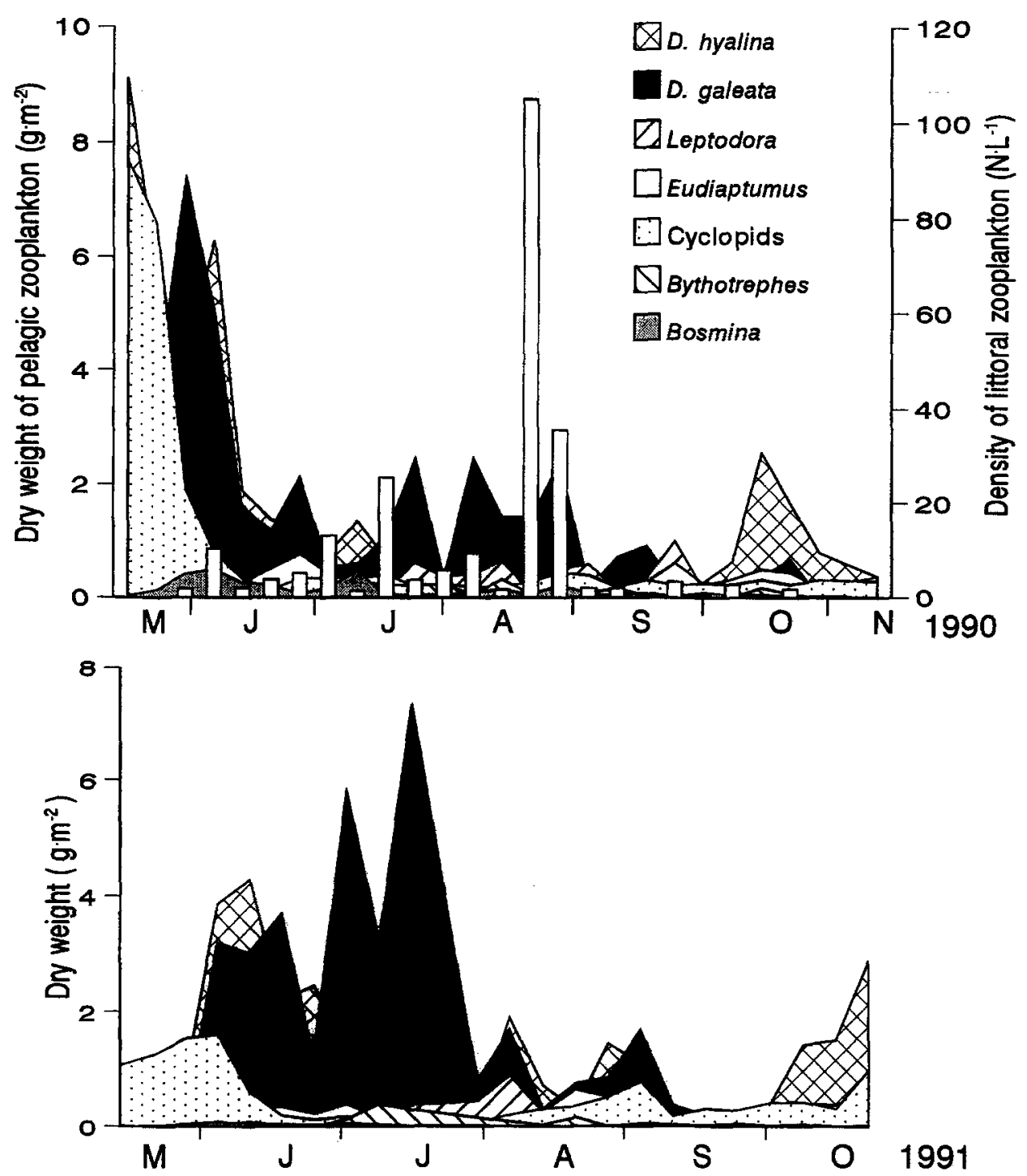

Fig. 3. Seasonal course of planktonic crustacean abundance in the pelagic zone (polygons, the data from Geller, Limnol. Inst. Constance) and the littoral zone (bars) of Lake Constance-Überlinger See in 1990 and 1991. Pelagic zooplankton was sampled with Clarke-Bumpus closing net of $100 \mu \mathrm{m}$ mesh size over the entire water column.

older perch occupied the same habitat (results of underwater observations and netting), and the occurrence of cannibalism was high $(11 \%, n=19$; $20 \%, n=21$ ). From mid-November onwards, few $0^{+}$perch were found by divers up to $30 \mathrm{~m}$ depth.

On three occasions during January and February 1992, divers observed shoals of $0^{+}$perch near the bottom at depths of 40-50 $\mathrm{m}$, but no older perch were seen around. On one occasion a group of adult perch was observed at $50 \mathrm{~m}$ depth without any $0^{+}$perch in its vicinity. Around midMarch, $0^{+}$perch were caught in the littoral zone again, and they were often caught together with older perch. During this period, cannibalism were frequently observed by the fishermen.

\section{Discussion}

The distribution patterns of larval and juvenile perch in Lake Constance are very similar to those 
Table 3. Depth distribution of juvenile perch resting on the bottom during the night in Lake Constance-Überlinger See, 1991. Mean numbers of fish counted by two divers along $20 \mathrm{~m}$ transects at six depth contours (large characters), and temperature profile (small characters) are given.

\begin{tabular}{|c|c|c|c|c|c|c|c|c|c|c|c|c|c|c|}
\hline \multirow{2}{*}{$\frac{\text { Depth }(\mathrm{m})}{2}$} & \multicolumn{2}{|c|}{10 Sept. } & \multicolumn{2}{|c|}{11 Oct. } & \multicolumn{2}{|c|}{21 Oct. } & \multicolumn{2}{|c|}{29 Oct. } & \multicolumn{2}{|c|}{6 Nov. } & \multicolumn{2}{|c|}{20 Nov. } & \multicolumn{2}{|c|}{29 Nov. } \\
\hline & 132 & $20.2^{\circ}$ & 21 & $15.1^{\mathrm{c}}$ & 1 & $11.3^{\circ}$ & 0 & $11.0^{\circ}$ & 0 & $10.0^{\circ}$ & 0 & $87^{\circ}$ & 0 & $7.9^{\circ}$ \\
\hline 5 & 391 & $20.0^{\circ}$ & 23 & $14.9^{\circ}$ & 4 & $11.3^{\circ}$ & 0 & $11.0^{\circ}$ & 1 & $9.9^{\circ}$ & 0 & $8.7^{\circ}$ & 0 & $7.9^{\circ}$ \\
\hline 10 & 31 & $19.3^{\circ}$ & 116 & $14.3^{\circ}$ & 6 & $11.2^{\circ}$ & 3 & $10.9^{\circ}$ & 4 & $9.2^{\circ}$ & 1 & $8.7^{\circ}$ & 0 & $7.9^{\circ}$ \\
\hline 15 & 1 & $12.7^{\circ}$ & 6 & $12.9^{\circ}$ & 2 & $10.9^{\circ}$ & 100 & $10.9^{\circ}$ & 13 & $9.1^{\circ}$ & 2 & $8.6^{\circ}$ & 0 & $7.9^{\circ}$ \\
\hline 20 & 0 & $9.8^{\circ}$ & 0 & $9.2^{\circ}$ & 5 & $9.9^{\circ}$ & 275 & $10.6^{\circ}$ & 84 & $8.7^{\circ}$ & 6 & $8.6^{\circ}$ & 0 & $7.9^{\circ}$ \\
\hline 25 & - & $8.9^{\circ}$ & - & $8.0^{\circ}$ & 6 & $9.5^{\circ}$ & 350 & $9.6^{\circ}$ & 235 & $7.9^{\circ}$ & 3 & $8.5^{\circ}$ & 0 & $7.9^{\circ}$ \\
\hline
\end{tabular}

which have been observed in other lakes. The finding of yolk-sac larvae of $5.3 \mathrm{~mm}$ mean length in the pelagical zone on 31 May 1991 (Fig. 1b; Table 1) supports the suggestion that early larval Perca are distributed according to water currents (Houde, 1969; Coles, 1981). Cannibalism on newly hatched larvae was not found in our study. The nearsurface distribution of the larvae might reduce the encounter probability with large perch which generally stay near the bottom. It might also be difficult for predators to recognize the small transparent larvae. Nevertheless, as long as habitat-specific risks are not quantified, no conclusion can be drawn about the relation between horizontal distribution of larval perch and predation pressure. Most larvae reached the pelagic zone within two weeks. During that time rotifers and nauplii (the main food of larvae during the first two weeks of life) were not consistently more abundant in the pelagic zone than in the littoral zone (Fig. 2). Hence, the argument that larval perch migrate offshore due to better feeding conditions is not supported by the present data.

Coles (1981) found that most of the larvae completed the inshore migration as the fins developed, and virtually all larvae had completed the migration at $19 \mathrm{~mm}$ total length. Similar lengths were reported for Eurasian perch by Nellen and Schnack (1974) and Treasurer (1988). Eurasian perch in Lake Constance, however, were far larger at completion of the inshore migration (>30 mm TL in 1990, >40 mm TL in 1991). Very different fish sizes at completion of the inshore migration were also reported for yellow perch (cf. Post \& McQueen, 1988). Whiteside et al. (1985) and Treasurer (1988), on the other hand, noted that the inshore migration coincided with a decline of pelagic zooplankton abundance. A similar result was found in our study: in both years, the majority of juveniles moved inshore when the pelagic zooplankton abundance declined (Figs 1-3). This happened during the first half of July in 1990, but during late July in 1991. These results support the hypothesis that the timing of inshore migration is related to the pelagic zooplankton abundance. Thus, the different sizes of young perch at completion of their inshore migration reported in the literature might

Table 4. Diel activity of $0^{+}$perch in Lake Constance-Überlinger See based on catches in gill nets. Numbers of fish caught by one gill net in 2-5 $\mathrm{m}$ depth at three times (in brackets) are given.

\begin{tabular}{llll}
\hline Date & Day & Twilight & Night \\
\hline 10.10 .90 & $14(15.00-16.00)$ & $32(17.15-18.15)$ & $17(19.00-20.00)$ \\
24.10 & $0(15.00-16.00)$ & $18(17.15-18.15)$ & $7(19.30-20.30)$ \\
26.10 & $0(10.00-11.00)$ & $15(6.30-7.30)$ & $0(4.00-5.00)$ \\
18.9 .91 & - & $>300(18.30-19.00)$ & $0(23.30-24.00)$ \\
\hline
\end{tabular}


reflect different time courses of zooplankton abundance between the study lakes or between the study years.

Failure to catch larvae during the day after mid-June might mainly be attributed to gear avoidance. It seems unlikely that larvae followed migrating zooplankton to deep and cold waters of more than $10 \mathrm{~m}$ depth, since their prey, nonmigrating $D$. galeata, is abundant in the upper layers. Furthermore, perch larvae always select warmer water layers in vertical temperature gradients of $16-26^{\circ} \mathrm{C}$ (unpublished data).

Prior to eutrophication of Lake Constance, large perch lived in shallow waters up to $5 \mathrm{~m}$ depth during summer and preyed on young conspecifics (Nümann, 1939). In parallel to lake eutrophication, adult perch moved progressively from the littoral to the sublittoral and they are nowadays distributed between 6 and $20 \mathrm{~m}$ depth from May to October (Hartmann \& Nümann, 1977; Hartmann \& Löffler, 1989). Zooplankton and, to minor degree, benthic invertebrates constitute their main food (Amann, 1975; Hartmann \& Nümann, 1977; Becker, 1988). The present study showed that after the completion of their inshore migration young perch did not disperse to the sublittoral but remained in shallow waters among submerged macrophyte stands and, thus, they were effectively out of the reach of larger perch. During the summer, young perch were not found in the stomachs of adult perch, except for mid-July 1991, when juveniles crossed the habitat of older conspecifics during their inshore migration. Other authors also reported low incidence of cannibalism during summer (Amann, 1975; Krämer \& Baroffio, 1988; Becker, 1988).

By late summer, juvenile perch changed their behavioural habit and presented a diel activity pattern. This change coincided with the decline of the submerged macrophytes, and with the decrease of zooplankton (Fig. 3) and chironomid larvae abundances (Knauer, 1991). At that time, $0^{+}$perch staying in the shallow waters found hardly any food at all and their growth decreased largely (the mean weekly specific growth rate in length: 0.16 in July and 0.11 in August, but 0.02 in September 1990). The daytime distribution of $0^{+}$perch, thus, appears to be shaped predominantly by the presence of adult perch in deeper water. At dusk, when the visual acuity of adult perch is decreasing (Ali et al., 1977) and pelagic zooplankton (mostly D. hyalina) migrate upwards, $0^{+}$perch moved offshore for foraging. During autumn, $0^{+}$perch visited increasingly deeper waters, and just during this period, the occurrence of cannibalism increased. Amann (1975) also noted that the peak of cannibalism ( $22 \%$ frequency of occurrence) occurred in October, although among the prey items of adult perch that could be identified $0^{+}$perch accounted for a small fraction only; in other months the frequency of occurrence was only $1.3 \%$. Increased incidence of cannibalism during October/ early November in our study was not related to zooplankton abundance, because during this period the abundance of D. hyalina, which are mainly distributed below $10 \mathrm{~m}$ depth and are the main food of large perch at that time, generally reaches a second maximum (Fig. 3). Krämer and Baroffio (1988) did not find a correlation between zooplankton density and cannibalism in Lake Constance, either. It is, therefore, suggested that the offshore movement of $0^{+}$perch in autumn, which was related to feeding on zooplankton, increased their vulnerability to predation.

Young perch left the littoral zone definitely and moved into deep waters when autumnal mixing occurred in late October. During overwintering in deep waters, $0^{+}$perch continued to stay apart from older perch, and cannibalism was not observed throughout the winter. Similar observations were reported by Amann (1975) and Hartmann (1975). During early spring, the frequent occurrence of cannibalism appeared to be associated with the inshore migration of both $0^{+}$and older perch. Becker (1988) only found perch cannibalism in March and April during his study between March and September.

The intensity of perch cannibalism depends on the size and abundance of young perch, on the abundance of alternative food sources, and on the size of the adults (Tarby, 1974; Hartmann, 1975; Craig, 1987). However, in our study, cannibalism appears to be related predominantly to the dis- 
tribution of both young and adult perch. During most of the year, young and adults were separated from each other. But as soon as they co-occurred in the same habitat, cannibalism took place. Therefore, perch cannibalism in Lake Constance might mainly be confined to three short periods:

(1) early summer during the inshore migration of early juveniles;

(2) autumn when $0^{+}$perch forage on zooplankton in offshore waters;

(3) early spring during the inshore migration of both $0^{+}$and adult perch after overwintering.

\section{Acknowledgements}

This study was supported by Deutscher Akademischer Austauschdienst (grant to N. Wang) and by Deutsche Forschungsgemeinschaft within the special collaborative program (SFB 248) 'Cycling of matter in Lake Constance'. We are grateful to $\mathrm{Mr}$ A. Sulger for his skilful assistance in all fishing operations, and Dr W. Geller for his unpublished data.

\section{References}

Ali, M. A., R. A. Ryder \& M. Anctil, 1977. Photoreceptors and visual pigments as related to behavioral responses and preferred habitats of perches (Perca spp.) and pikeperches (Stizostedion spp.). J. Fish. Res. Bd Can. 34: 14751480 .

Amann, E., 1975. Nahrungsumstellung und Zunahme der Barsche (Perca fluviatilis) im Bodensee-Obersee infolge Eutrophierung. Österr. Fisch. 28: 72-76.

Becker, M, 1988. Freilandökologische Untersuchungen an planktivoren Fischen des Uberlinger Sees mit Schwerpunkt einer differenzierten Nahrungsanalyse. M. Sc. thesis, University of Constance.

Coles, T. F., 1981. The distribution of perch, Perca fluviatilis
L. throughout their first year of life in Llyn Tegid, North Wales. J. Fish Biol. 18: 15-30.

Craig, J., 1987. The biology of perch and related fish. Croom Helm, London: 333 pp.

Geller, W., 1986. Diurnal vertical migration of zooplankton in a temperate great lake (L. Constance): A starvation avoidance mechanism? Arch. Hydrobiol. Suppl. 74: 1-60.

Hartmann, J., 1975. Der Barsch (Perca fluviatilis) im eutrophierten Bodensee. Arch. Hydrobiol. 76: 269-286.

Hartmann, J. \& H. Löffler, 1989. Tiefenverteilung der Fische des Bodensees. Österr. Fisch. 42: 236-240.

Hartmann, J. \& W. Nümann, 1977. Percids of Lake Constance, a lake undergoing eutrophication. J. Fish. Res. Bd Can. 34: 1670-1677.

Houde, E. D., 1969. Distribution of larval walleyes and yellow perch in a bay of Oneida Lake and its relation to water currents and zooplankton. N.Y. Fish Game J. 16: 184-205.

Knauer, K., 1991. Vergleich litoraler Biozönosen vor verbauten und unverbauten Uferabschnitten des Bodensees (Konstanz-Egg). M. Sc. thesis, University of Constance. Krämer, A. \& C. Baroffio, 1988. Nahrungswahl und Kannibalismus beim Barsch (Perca fluvatilis) des BodenseeObersees. Schweiz. Fischereiwissensch. 2: 3-4.

Nellen, W. \& D. Schnack, 1974. Sampling problems and methods of fish eggs and larvae investigations with special reference to inland waters. In: EIFAC symposium on methodology for the survey, monitoring and appraisal of fishery resources in lakes and large rivers. Oben, Scotland. Contribution No. 57.

Nümann, W., 1939. Untersuchungen über die Biologie einiger Bodenseefische in der Uferregion und den Randgebieten des freien Sees. Z. Fisch. 37: 637-688.

Post, J. R. \& D. J. McQueen, 1988. Ontogenetic changes in the distribution of larval and juvenile yellow perch (Perca flavescens): a response to prey or predators? Can. J. Fish. aquat. Sci. 45: $1820-1826$.

Tarby, M. J., 1974. Characteristics of yellow perch cannibalism in Oneida Lake and the relation to first year survival. Trans. am. Fish. Soc. 3: 462-471.

Treasurer, J. W., 1988. The distribution and growth of lacustrine $0^{+}$perch, Perca fluvatilis. Envir. Biol. Fish. 21: 37-44.

Wang, N., 1993. Food and Feeding of young perch (Perca fluviatilis L.) in Lake Constance. Verh. Int. Ver. Limnol. 25. (in press).

Whiteside, M., C. M. Swindoll \& W. L. Doolittle, 1985. Factors affecting the early life history of yellow perch, Perca flavescens. Envir. Biol. Fish. 2: 47-56. 